\title{
Differentiation between the Genera Rhodococcus and Nocardia and between Species of the Genus Mycobacterium by Susceptibility to Bleomycin
}

\author{
By MICHIO TSUKAMURA \\ The National Chubu Hospital, Obu, Aichi, Japan 474
}

(Received 28 August 1981; revised 6 February 1982)

Susceptibility to bleomycin proved to be a useful criterion for differentiating Rhodococcus from Nocardia, the former being susceptible and the latter resistant to this agent. The test was also useful for discriminating between various species of the genus Mycobacterium.

\section{INTRODUCTION}

Recently susceptibility tests to 5-fluorouracil and to mitomycin $\mathrm{C}$ were reported to be useful for discriminating between the genera Rhodococcus and Nocardia, as the former was susceptible and the latter resistant to these agents (Tsukamura, $1981 \mathrm{a}, 1981 \mathrm{~b}$ ). Another anticancer agent, bleomycin, has been tested for its ability to differentiate between these two genera and between various species of the genus Mycobacterium.

\section{METHODS}

Strains. All strains used were from the collection of this laboratory.

Media. Modified Sauton agar and Ogawa egg media were used. The composition of the modified Sauton agar medium was as follows: glycerol, $30 \mathrm{ml} ; \mathrm{K} \mathrm{H}_{2} \mathrm{PO}_{4}, 0.5 \mathrm{~g} ; \mathrm{MgSO}_{4} .7 \mathrm{H}_{2} \mathrm{O}, 0.5 \mathrm{~g}$; citric acid, $2.0 \mathrm{~g}$; ferric ammonium citrate, $0.05 \mathrm{~g}$; sodium glutamate, $4.0 \mathrm{~g}$; purified agar (Eiken Company, Tokyo), 20.0 g; distilled water, $970 \mathrm{ml}$. The medium was adjusted to $\mathrm{pH} 7 \cdot 0$ with $10 \%(\mathrm{w} / \mathrm{v}) \mathrm{KOH}$ solution. The medium was sterilized by autoclaving at $120^{\circ} \mathrm{C}$ for $20 \mathrm{~min}$. Bleomycin hydrochloride (Nippon Kayaku Company, Tokyo) was added aseptically to the medium after the latter had been liquefied by heating in a water-bath $\left(100{ }^{\circ} \mathrm{C}\right)$. The following concentrations of bleomycin were used: $10,5,2 \cdot 5,1 \cdot 25$, and $0 \mu \mathrm{g} \mathrm{ml}^{-1}$. The bleomycin-containing media were distributed in $7 \mathrm{ml}$ quantities into tubes, $165 \times 16.5 \mathrm{~mm}$, and solidified as slopes. The composition of the Ogawa egg medium was as follows: basal solution [ $1 \%(\mathrm{w} / \mathrm{v}) \mathrm{KH}_{2} \mathrm{PO}_{4}$ and $1 \%(\mathrm{w} / \mathrm{v})$ sodium glutamate], $100 \mathrm{ml}$; whole eggs, $200 \mathrm{ml}$; glycerol, $6 \mathrm{ml} ; 2 \%(\mathrm{w} / \mathrm{v})$ aqueous solution of malachite green, $6 \mathrm{ml}(\mathrm{pH} \mathrm{6.8)}$. Bleomycin and other anticancer agents (see Table 1) were added to the Ogawa egg medium before sterilization. The medium was distributed in $7 \mathrm{ml}$ quantities into tubes, $165 \times 16.5 \mathrm{~mm}$, and sterilized by heating at $90^{\circ} \mathrm{C}$ for $60 \mathrm{~min}$, thereby coagulating it as slopes.

Test strains of rapidly growing mycobacteria, rhodococci and nocardiae were cultivated at $37^{\circ} \mathrm{C}$ (nocardiae, $28^{\circ} \mathrm{C}$ ) for $5 \mathrm{~d}$ and slowly growing mycobacteria were cultivated at $37^{\circ} \mathrm{C}$ for $14 \mathrm{~d}$ on Ogawa egg medium. From these cultures, a bacterial suspension, approximately $1 \mathrm{mg}$ wet weight $\mathrm{ml}^{-1}$, was prepared. A sample $(0.02 \mathrm{ml})$ of these suspensions was inoculated on to each medium by use of a spiral loop. The medium was stoppered with a double-edged gum cap having a $3 \mathrm{~mm}$ cut in the centre of its base and incubated at $37^{\circ} \mathrm{C}$ (nocardiae, $28^{\circ} \mathrm{C}$ ) for $5 \mathrm{~d}$ (slowly growing mycobacteria, $14 \mathrm{~d}$ ). Confluent growth similar to that on the control medium was scored positive. Partial growth was observed sometimes, but this was regarded as negative. In most cases, the reading was clearcut.

\section{RESULTS AND DISCUSSION}

The inhibitory activity of seven anticancer agents tested in Ogawa egg medium is shown in Table 1 .

A pilot study on the action of bleomycin showed that the reading of the inhibitory concentration is more clear-cut with Sauton agar medium than with Ogawa egg medium. Hence, the test for susceptibility to bleomycin of rapidly growing mycobacteria, rhodococci, and nocardiae, which grow well on this medium, was carried out with modified Sauton agar medium. Slowly 
Table 1. Comparison of susceptibilty to various anticancer agents of Mycobacterium, Rhodococcus and Nocardia grown on Ogawa egg medium

\begin{tabular}{|c|c|c|c|c|}
\hline & \multicolumn{4}{|c|}{ Minimum inhibitory concentration $\left(\mu \mathrm{g} \mathrm{ml}^{-1}\right)$} \\
\hline & $\begin{array}{l}\text { Mycobacterium } \\
\text { thermoresistibile }\end{array}$ & $\begin{array}{c}\text { Mycobacterium } \\
\text { aurum }\end{array}$ & $\begin{array}{c}\text { Rhodococcus } \\
\text { bronchialis }\end{array}$ & $\begin{array}{l}\text { Nocardia } \\
\text { asteroides }\end{array}$ \\
\hline Anticancer agent* & ATCC 19527 & ATCC 23366 & ATCC 25592 & ATCC 19247 \\
\hline rouracil & $<5$ & $<5$ & $<5$ & $>40$ \\
\hline iycin C & $1 \cdot 25$ & 1.25 & 5 & $>10$ \\
\hline ycin hydrochloride & $2 \cdot 5$ & $2 \cdot 5$ & 5 & $>20$ \\
\hline nomycin A3 & 10 & 5 & 10 & 10 \\
\hline abicin hydrochloride & $>20$ & $>20$ & $>20$ & $>20$ \\
\hline hosphamide & $>20$ & $>20$ & $>20$ & $>20$ \\
\hline ine arabinoside & $>20$ & $>20$ & $>20$ & $>20$ \\
\hline
\end{tabular}

* Sources: 5-Fluorouracil and doxorubicin hydrochloride, Kyowa Hakko Co., Tokyo; mitomycin C, Sanko Co., Tokyo; bleomycin hydrochloride, Nippon Kayaku Co., Tokyo; chromomycin A3, Takeda Chemical Co., Osaka; cyclophosphamide, Shionogi Co., Osaka; cytosine arabinoside, Nippon Shiyaku Co., Kyoto.

Table 2. Susceptibility to bleomycin of rapidly growing mycobacteria, rhodococci and nocardiae grown on modified Sauton agar medium

Figures in parentheses indicate numbers of strains that showed only thin confluent growth.

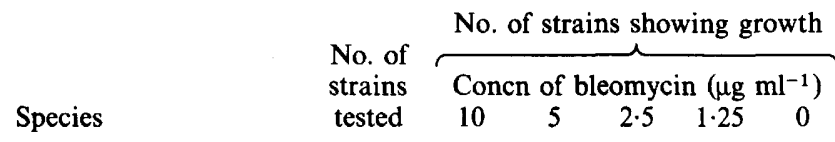

\begin{tabular}{|c|c|}
\hline \multirow{2}{*}{$\begin{array}{l}\text { No. of } \\
\text { strains }\end{array}$} & No. of strains showing growth \\
\hline & Concn of bleomycin $\left(\mu \mathrm{g} \mathrm{ml}^{-1}\right)$ \\
\hline sted & $1 \cdot 25$ \\
\hline
\end{tabular}

\section{Mycobacterium}

Rapidly-growing, non-photochromogenic

M. smegmatis

$M$. fortuitum

$M$. chelonei subsp. chelonei

$M$. chelonei subsp. abscessus*

M. chitae

M. agri

'M. diernhoferi'

Rapidly-growing, photochromogenic

M. vaccae

$M$. parafortuitum

Rapidly-growing, scotochromogenic

M. phlei

$M$. flavescens

$M$. thermoresistibile

$M$. aurum $\dagger$

$M$. rhodesiae

$M$. neoaurum

$M$. obuense

$M$. aichiense

$M$. chubuense

M. tokaiense

'M. austroafricanum'

$\begin{array}{rrrrrr}5 & 5 & 5 & 5 & 5 & 5 \\ 10 & 10 & 10 & 10 & 10 & 10 \\ 10 & 10 & 10 & 10 & 10 & 10 \\ 10 & 4 & 4 & 8 & 10 & 10 \\ 5 & 0 & 0 & 3 & 5 & 5 \\ 5 & 0 & 0 & 0 & 0 & 5 \\ 5 & 0 & 0 & 0 & 0 & 5\end{array}$

Rhodococcus
$R$. rhodochrous
$R$. bronchialis
$R$. rubropertinctus
$R$. terrae
$R$. ruber
R. equi
R. coprophilus

$\begin{array}{rccccc}5 & 0 & 0 & 1 & 2 & 5 \\ 5 & 0 & 0 & 2 & 4 & 5 \\ 5 & 0 & 0 & 0 & 1 & 5 \\ 5 & 0 & 0 & 0 & 0 & 5 \\ 5 & 0 & 0 & 0 & 5 & 5 \\ 5 & 2 & 2 & 2 & 4 & 5 \\ 5 & 0 & 0 & 4 & 5 & 5 \\ 5 & 5 & 5 & 5 & 5 & 5 \\ 5 & (5) & (5) & 5 & 5 & 5 \\ 5 & (5) & (5) & 5 & 5 & 5 \\ 5 & 0 & (4) & 5 & 5 & 5 \\ 4 & 0 & 0 & 2 & 4 & 4 \\ 5 & 0 & 0 & 0 & 0 & 5 \\ & & & & & \\ & & & & & \\ 10 & 0 & 0 & 2 & 3 & 10 \\ 10 & 0 & 0 & 0 & 4 & 10 \\ 10 & 0 & 0 & 0 & 0 & 10 \\ 10 & 0 & 0 & 0 & 0 & 10 \\ 6 & 0 & 0 & 0 & 0 & 6 \\ 2 & 0 & 0 & 0 & 0 & 2 \\ 2 & 0 & 0 & 0 & 0 & 2\end{array}$


Table 2 (continued)

$\quad$ Species
Nocardia
N. asteroides
N. farcinica
N. brasiliensis
N. otitidis-caviarum
'Gordona'
'Gordona aurantiaca'

\begin{tabular}{|c|c|c|c|c|c|}
\hline \multirow{3}{*}{$\begin{array}{l}\text { No. of } \\
\text { strains } \\
\text { tested }\end{array}$} & \multicolumn{5}{|c|}{ No. of strains showing growth } \\
\hline & \multicolumn{5}{|c|}{ Concn of bleomycin $\left(\mu \mathrm{g} \mathrm{ml}^{-1}\right)$} \\
\hline & 10 & 5 & $2 \cdot 5$ & $1 \cdot 25$ & 0 \\
\hline 33 & 22 & 25 & 28 & 29 & 33 \\
\hline 51 & 40 & 45 & 51 & 51 & 51 \\
\hline 5 & 4 & 5 & 5 & 5 & 5 \\
\hline 9 & 9 & 9 & 9 & 9 & 9 \\
\hline 10 & 0 & 0 & 8 & 10 & 10 \\
\hline
\end{tabular}

* Six strains including the type strain ATCC 19977 were susceptible to $5 \mu \mathrm{g} \mathrm{ml}^{-1}$ and four strains including the strain ATCC 14472 were resistant to $10 \mu \mathrm{g} \mathrm{ml}^{-1}$.

$\dagger$ The type strain ATCC 23366 was susceptible to $2.5 \mu \mathrm{g} \mathrm{ml}^{-1}$.

Table 3. Susceptibility to bleomycin of slowly growing mycobacteria grown on Ogawa egg medium

\begin{tabular}{|c|c|c|c|c|c|c|}
\hline \multirow[b]{3}{*}{ Species } & \multirow{3}{*}{$\begin{array}{l}\text { No. of } \\
\text { strains } \\
\text { tested }\end{array}$} & \multicolumn{5}{|c|}{ No. of strains showing growth } \\
\hline & & \multicolumn{5}{|c|}{ Concn of bleomycin $\left(\mu \mathrm{g} \mathrm{ml}^{-1}\right)$} \\
\hline & & 20 & 10 & 5 & 2.5 & 0 \\
\hline M. tuberculosis & 5 & 0 & 0 & 0 & 0 & 5 \\
\hline M. bovis & 5 & 0 & 0 & 0 & 0 & 5 \\
\hline M. kansasii & 5 & 0 & 0 & 0 & 0 & 5 \\
\hline M. marinum & 5 & 5 & 5 & 5 & 5 & 5 \\
\hline$M$. simiae & 5 & 5 & 5 & 5 & 5 & 5 \\
\hline M. asiaticum & 5 & 4 & 5 & 5 & 5 & 5 \\
\hline M. avium & 20 & 14 & 16 & 20 & 20 & 20 \\
\hline$M$. intracellulare & 30 & 5 & 7 & 13 & 27 & 30 \\
\hline M. scrofulaceum & 10 & 0 & 0 & 0 & 0 & 10 \\
\hline M. szulgai & 5 & 0 & 0 & 5 & 5 & 5 \\
\hline M. gordonae & 10 & 1 & 1 & 5 & 8 & 10 \\
\hline M. xenopi & 5 & 0 & 0 & 0 & 0 & 5 \\
\hline M. shimoidei & 3 & 0 & 0 & 0 & 1 & 3 \\
\hline M. nonchromogenicum & 10 & 8 & 8 & 10 & 10 & 10 \\
\hline$M$. terrae & 10 & 4 & 4 & 4 & 6 & 10 \\
\hline M. triviale & 10 & 0 & 0 & 0 & 0 & 10 \\
\hline M. gastri & 5 & 0 & 0 & 0 & 0 & 5 \\
\hline
\end{tabular}

growing mycobacteria were tested on Ogawa egg medium, as some species of this group showed only scanty or no growth on Sauton agar medium.

Apart from several strains of Nocardia asteroides sensu stricto (Tsukamura, 1969), all Nocardia strains were resistant to at least $2 \cdot 5 \mu \mathrm{g}$ bleomycin $\mathrm{ml}^{-1}$, whereas almost all Rhodococcus strains were susceptible to this concentration (Table 2).

The test for susceptibility to bleomycin was also useful for differentiating between species of rapidly growing mycobacteria (Table 2 ). Of the rapidly growing, non-photochromogenic mycobacteria, only $M$. smegmatis, $M$. fortuitum and $M$. chelonei subsp. chelonei were resistant to $10 \mu \mathrm{g} \mathrm{ml}^{-1}$. Strains of $M$. chelonei subsp. abscessus were heterogeneous in respect to the susceptibility to bleomycin.

Of the slowly growing mycobacteria. $M$. avium, $M$. intracellulare, $M$. scrofulaceum and $M$. asiaticum were previously shown to be closely related to each other (Tsukamura, 1976). Of these four species, only $M$. scrofulaceum was sensitive to bleomycin (Table 3). Mycobacterium nonchromogenicum, $M$. terrae and $M$. triviale were also shown to be closely related to each other (Tsukamura, 1976), but only $M$. nonchromogenicum was resistant to bleomycin while $M$. triviale was sensitive. Strains of $M$. terrae showed varying degrees of susceptibility to bleomycin (Table 3). The type strain (ATCC 15755) of this species was resistant to $20 \mu \mathrm{g}$ bleomycin $\mathrm{ml}^{-1}$. Mycobacterium gordonae also was heterogeneous in its susceptibility to this agent. 


\section{REFERENCES}

TsUKAMURA, M. (1969). Numerical taxonomy of the genus Nocardia. Journal of General Microbiology 56, 265-287.

TsUkAMURA, M. (1976). Numerical classification of slowly growing mycobacteria. International Journal of Systematic Bacteriology 26, 409-420.

TsukamuRA, M. (1981 $a$ ). Differentiation between the genera Mycobacterium, Rhodococcus and Nocardia by

susceptibility to 5-fluorouracil. Journal of General Microbiology 125, 205-208.

TsukamuRA, M. (1981 b). Test for susceptibility to mitomycin $\mathrm{C}$ as aids for differentiating the genus $R$ hodococcus from the genusNocardia, and for differentiating Mycobacterium fortuitum and Mycobacterium chelonei from other rapidly growing mycobacteria. Microbiology and Immunology 25, 1197-1199. 